\title{
Dyella japonica gen. nov., sp. nov., a $\gamma$-proteobacterium isolated from soil
}

Correspondence
Cheng-Hui Xie
aa37116@mail.ecc.u-tokyo.ac.jp

\author{
Cheng-Hui Xie and Akira Yokota \\ Institute of Molecular and Cellular Biosciences, The University of Tokyo, Yayoi 1-1-1, \\ Bunkyo-Ku, Tokyo 113-0032, Japan
}

Three bacterial strains, $\mathrm{XD} 10, \mathrm{XD} 22$ and $\mathrm{XD} 53^{\mathrm{T}}$, were isolated from soil during the course of the isolation of diazotrophs from a garden at the University of Tokyo, Japan. These isolates neither fix nitrogen nor have the nifH gene (Poly et al., 2001). On the basis of 16S rRNA gene sequence analysis, these yellow-pigmented soil isolates seemed to represent a novel and important group within the $\gamma$-Proteobacteria and were closely related to the plasticized acetylated starch-degrading bacterium Fulvimonas soli (Mergaert et al., 2002), the lindane-degrading bacterium Rhodanobacter lindaniclasticus (Nalin et al., 1999) and the acidophilic bacterium Frateuria aurantia (Swings et al., 1984). Upon comparison of the metabolism of the novel bacterium with those of its phylogenetic neighbours, we found that it was not acidophilic like members of the genus Frateuria; however, it was not known if the organism possessed the ability to degrade plasticized acetylated starch or lindane. The aim of this study was to elucidate the phylogenetic position of the isolates, using polyphasic taxonomy (physiology, fatty acid composition, quinone system, DNA G $+\mathrm{C}$ content, DNADNA relatedness and $16 \mathrm{~S}$ rRNA gene sequence analysis). On the basis of this substantial evidence, it is proposed that the isolates represent a novel species in a novel genus, Dyella

Published online ahead of print on 22 October 2004 as DOI 10.1099/ ijs.0.63377-0.

The GenBank/EMBL/DDBJ accession numbers for the 16S rRNA gene sequences of strains XD10, XD22 and XD53 ${ }^{\top}$ are AB110496AB1 10498. japonica gen. nov., sp. nov. The type strain is $\mathrm{XD}^{2} 3^{\mathrm{T}}$ (=IAM $15069^{\mathrm{T}}=\operatorname{DSM} 16301^{\mathrm{T}}=$ ATCC BAA-939 ${ }^{\mathrm{T}}$ ).

The cells used for tests of growth at various temperatures and $\mathrm{pH}$ values were incubated in nutrient broth. Cell shape, size and motility were observed by light microscopy (BX 60 apparatus; Olympus). The presence of flagella was determined by transmission electron microscopy (JEM-1011 apparatus; JEOL) after negative staining with uranyl acetate. Gram staining was performed using the method of OyaizuMasuchi \& Komagata (1988). API 20NE, API $50 \mathrm{CH}$ and API ZYM tests (all bioMérieux) were used to determine physiological and biochemical characteristics. The API ZYM test results were read after $4 \mathrm{~h}$ incubation at $28^{\circ} \mathrm{C}$; all other API tests were read after $48 \mathrm{~h} . \mathrm{H}_{2} \mathrm{~S}$ formation was detected with lead acetate paper strips in GPY medium containing $(\mathrm{w} / \mathrm{v}) 5 \%$ D-glucose, $0.5 \%$ peptone, $0.2 \%$ yeast exact, $0 \cdot 1 \%$ L-cysteine and $0 \cdot 005 \% \mathrm{Na}_{2} \mathrm{SO}_{4}$. The bacteria were incubated at $28^{\circ} \mathrm{C}$ on a rotary shaker in $\mathrm{AE}$ broth [1.5\% (w/v) glucose, $0 \cdot 2 \%(\mathrm{w} / \mathrm{v})$ yeast extract, $0 \cdot 3 \%(\mathrm{w} / \mathrm{v})$ peptone, $6.5 \%(\mathrm{v} / \mathrm{v})$ acetic acid and $2 \%(\mathrm{v} / \mathrm{v})$ ethanol] (Entani et al., 1985) for 30 days; AE broth was used to identify the genus Frateuria (Swings et al., 1984). Examination of the respiratory quinone system, DNA G $+\mathrm{C}$ content and cellular fatty acid composition, PCR-mediated amplification of $16 \mathrm{~S}$ rRNA gene sequences and sequencing of the PCR products were carried out as described previously (Xie \& Yokota, 2003). DNA was prepared according to the method of Marmur (1961) from cells grown on nutrient broth and DNA G + C contents were determined by using 


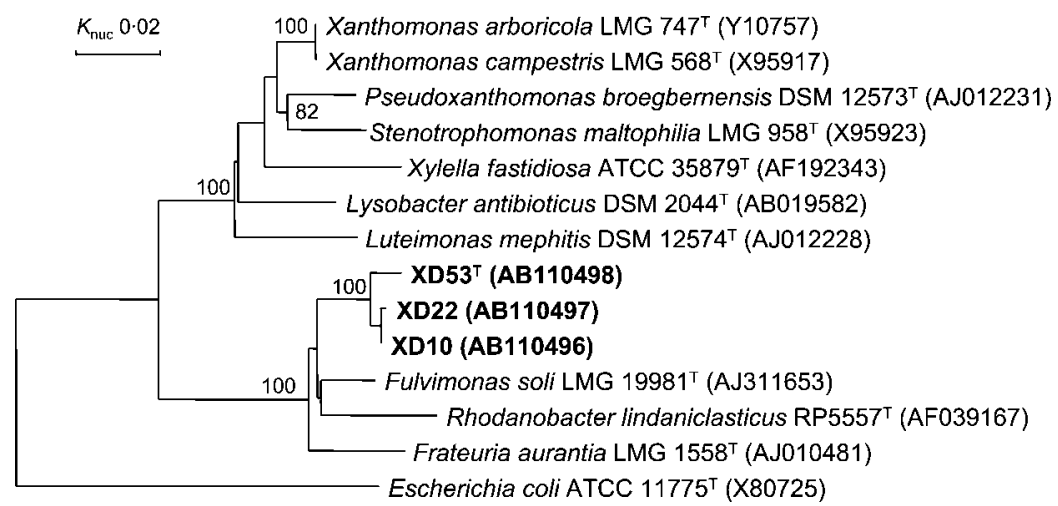

Fig. 1. Phylogenetic tree of a subset of the $\gamma$-Proteobacteria, based on 16S rRNA gene sequence comparison, determined by neighbour-joining. Escherichia coli was used as the outgroup. Bootstrap percentages of 1000 replicates are indicated at nodes; only values greater than $70 \%$ are shown.

the HPLC method of Mesbah et al. (1989). DNA-DNA hybridizations were carried out with photobiotin-labelled probes in microplate wells as described by Ezaki et al. (1989). The hybridization temperature was set at $51^{\circ} \mathrm{C}$.

The DNA sequences of the three strains were compared with sequences obtained from GenBank (National Centre for Biotechnology Information). The sequences were aligned using the CLUSTAL W software package (Thompson et al., 1994) and evolutionary distances and $K_{\text {nuc }}$ values (Kimura, $1980)$ were generated. Alignment gaps and ambiguous bases were not taken into consideration when 1433 bases of the 16S rRNA gene sequences were compared. Phylogenetic trees were constructed using either the neighbour-joining method (Saitou \& Nei, 1987) or the maximum-likelihood method (PHYLIP package; Felsenstein, 1989). The topology of the phylogenetic tree was evaluated by using the bootstrap resampling method of Felsenstein (1985), with 1000 replicates. Similarity values were calculated using PAUP 4.0b1 (Swofford, 1998).

The 16S rRNA gene sequences of the three strains were determined and subjected to comparative analysis. The sequence of strain $\mathrm{XD}^{\mathrm{T}} 3^{\mathrm{T}}$ showed high similarity (more than $99.0 \%$ ) to those of the other two strains. The phylogenetic tree (Fig. 1) shows that these strains are clustered within the family 'Xanthomonadaceae' of the $\gamma$-Proteobacteria. The levels of $16 \mathrm{~S}$ rRNA gene sequence similarity between $\mathrm{XD} 53^{\mathrm{T}}$ and Fulvimonas soli LMG $19981^{\mathrm{T}}$ (Mergaert et al., 2002), Frateuria aurantia LMG $1558^{\mathrm{T}}$ and Rhodanobacter lindaniclasticus RP $5557^{\mathrm{T}}$ (Nalin et al., 1999) were 96.5, 95.9 and $95.0 \%$, respectively. A similarity value of no more than $97 \%$ between $16 \mathrm{~S}$ rRNA gene sequences is widely accepted for genus-level differentiation (Gillis et al., 2001). The bootstrap value for the branching of Frateuria aurantia LMG $1558^{\mathrm{T}}$ and the novel strains was less than $70 \%$ (data not shown). The phylogenetic tree calculated by the maximum-likelihood method (data not shown) also supported the contention that these novel isolates represented an independent taxon separated from the genera Fulvimonas, Frateuria and Rhodanobacter.

The DNA-DNA hybridization values for XD10 and XD53 ${ }^{\mathrm{T}}$ and of XD22 and XD10 were $87 \cdot 2$ and $99 \cdot 7 \%$, respectively. The three strains should therefore be considered as belonging to the same species. The DNA G+C contents of strains $\mathrm{XD} 10, \mathrm{XD} 22$ and $\mathrm{XD}^{\mathrm{T}}{ }^{\mathrm{T}}$ were $64 \cdot 0,63 \cdot 4$ and $63.5 \mathrm{~mol} \%$, respectively; these values are quite different from those of members of the genus Fulvimonas (71.7\%). The cellular fatty acid patterns of these strains displayed similar compositions (Table 1). They were found to consist primarily of branched fatty acids, with $17: 1$ iso $\omega 9 c$ $(25 \cdot 6-30 \cdot 8 \%), 15: 0$ iso $(20 \cdot 0-23 \cdot 6 \%)$ and $17: 0$ iso $(19 \cdot 6-$ $20.0 \%)$ as major constituents. The major hydroxy fatty acids were 11:0 iso 3-OH, 13:0 iso $3-\mathrm{OH}$ and 17:0 iso 3$\mathrm{OH}$. This cellular fatty acid composition can be differentiated from that of Frateuria aurantia, which contains

Table 1. Fatty acid composition of strains XD10, XD22 and $\mathrm{XD}^{\mathrm{T}} 3^{\mathrm{T}}$

The following fatty acids constituted no more than $0.5 \%$ of the total: unknown $9 \cdot 531,12: 0$ anteiso, $13: 0$ iso, $12: 0$ iso $3-\mathrm{OH}$, unknown 13.65, 14:0 iso, 14:0, 16:0 N alcohol, 17:0 anteiso, $16: 0$ iso $3-\mathrm{OH}, 18: 0$ iso, $18: 0$ and $20: 0$. Summed feature 3 comprises $15: 0$ iso $2-\mathrm{OH}$ and/or $16: 1 \omega 7 c$.

\begin{tabular}{|lcrr|}
\hline Fatty acid & XD10 & XD22 & XD53 $^{\mathbf{T}}$ \\
\hline $11: 0$ iso & $3 \cdot 5$ & $4 \cdot 1$ & $3 \cdot 8$ \\
Unknown ECL $11 \cdot 799^{*}$ & $1 \cdot 8$ & $1 \cdot 9$ & $1 \cdot 9$ \\
$11: 0$ iso 3-OH & $3 \cdot 5$ & $3 \cdot 9$ & $3 \cdot 7$ \\
$13: 0$ iso 3-OH & $3 \cdot 6$ & $4 \cdot 1$ & $3 \cdot 9$ \\
$15: 0$ iso & $22 \cdot 9$ & $20 \cdot 0$ & $23 \cdot 6$ \\
$15: 0$ anteiso & $1 \cdot 0$ & $1 \cdot 2$ & $1 \cdot 6$ \\
$16: 0$ iso & $2 \cdot 5$ & $4 \cdot 1$ & $4 \cdot 9$ \\
$16: 0$ & $1 \cdot 70$ & $1 \cdot 6$ & $1 \cdot 5$ \\
$17: 1$ iso $\omega 9 c$ & $30 \cdot 8$ & $28 \cdot 3$ & $25 \cdot 6$ \\
$17: 0$ iso & $19 \cdot 6$ & $21 \cdot 6$ & $20 \cdot 0$ \\
$17: 0$ anteiso & $0 \cdot 4$ & $0 \cdot 5$ & $0 \cdot 7$ \\
$17: 0$ iso 3-OH & $1 \cdot 0$ & $1 \cdot 0$ & $1 \cdot 1$ \\
$19: 0$ iso & $0 \cdot 7$ & $0 \cdot 6$ & $0 \cdot 7$ \\
Summed feature 3 & $4 \cdot 0$ & $3 \cdot 6$ & $4 \cdot 0$ \\
& & & \\
\hline
\end{tabular}

${ }^{\star}$ Unknown peak that appeared at $11.799 \mathrm{~min}$. 


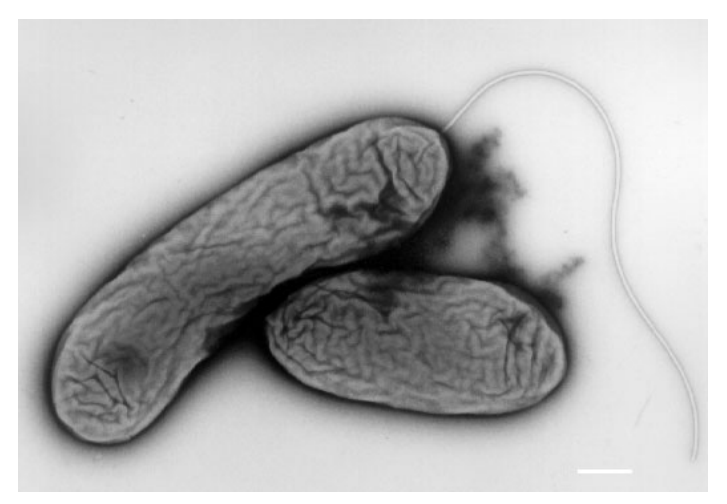

Fig. 2. Cells of $D$. japonica $X D 53^{\top}$ after negative staining with uranyl acetate, as visualized by transmission electron microscopy, showing a single, polar, attached flagellum. Bar, $0.2 \mu \mathrm{m}$.

more than $40 \cdot 6 \% 15: 0$ iso and not more than $3 \% 17: 1$ iso $\omega 9 c$, and has $12: 03-\mathrm{OH}$ and $12: 02-\mathrm{OH}$ as the major hydroxy fatty acids (Lisdiyanti et al., 2003). On the other hand, we found that the hydroxy fatty acid profile of Fulvimonas soli contained 12:0 iso $3-\mathrm{OH}$ and did not contain 17:0 iso 3-OH (Mergaert et al., 2002). Ubiquinone Q-8 was detected as the major quinone system in these isolates; this is similar to the situation in Frateuria aurantia.
Colonies are yellow in nutrient agar. Cells of strain $\mathrm{XD} 53^{\mathrm{T}}$ are straight rods, approximately $0.4 \mu \mathrm{m}$ in diameter and $1 \cdot 2 \mu \mathrm{m}$ in length, and each possesses a single polar flagellum (Fig. 2). Motility could be observed in the cells of all strains. All strains could grow slowly at 10 or $37^{\circ} \mathrm{C}$, but could not grow at 4 or $40^{\circ} \mathrm{C}$. The optimum temperature for growth was $25-30^{\circ} \mathrm{C}$. The optimum $\mathrm{pH}$ was $6 \cdot 5-7 \cdot 2$; the strains could not grow at $\mathrm{pH} 4 \cdot 6$. Biochemical and physiological characteristics of the strains were determined by using the API microtest galleries (bioMérieux): the strains displayed similar characteristics. All were catalase-positive, oxidasenegative, nitrate reduction-positive, nitrite reductionnegative, $\mathrm{H}_{2} \mathrm{~S}$-negative, produced acid from glucose, fructose and mannose and grew on maltose. In terms of biochemical characteristics, positive test results were obtained for $\mathrm{N}$-acetylglucosamine, alkaline phosphatase, C4 esterase lipase, C8 esterase lipase, C14 lipase, leucine arylamidase, valine arylamidase, acid phosphatase and naphthol phosphohydrolase, weak reactions were obtained for $N$-acetyl- $\beta$-D-glucosamine and negative reactions were obtained for $\beta$-glucuronidase, urease, gelatin liquefaction, indole production and growth on mannitol, caprate, valerate, $\mathrm{D}$-ribose, $\mathrm{D}$-sucrose, acetate, $\mathrm{L}$-alanine, citrate, histidine, D-ribose, hydroxybenzoate, $p$-nitrophenyl $\beta$ D-galactopyranoside, trypsin, $\alpha$-galactosidase, aesculin, malate, arginine, $\beta$-galactosidase, $\alpha$-mannosidase, $\alpha$ fucosidase and D-xylose. These strains can be differentiated

Table 2. Differential characteristics among Fulvimonas, Frateuria, Rhodanobacter and Dyella gen. nov.

Species: 1, Dyella japonica gen. nov., sp. nov.; 2, Frateuria aurantia; 3, Fulvimonas soli; 4, Rhodanobacter lindaniclasticus. Data for reference species are from Mergaert et al. (2002). Members of all four genera are catalase-positive. +, Positive; -, negative; ND, not determined.

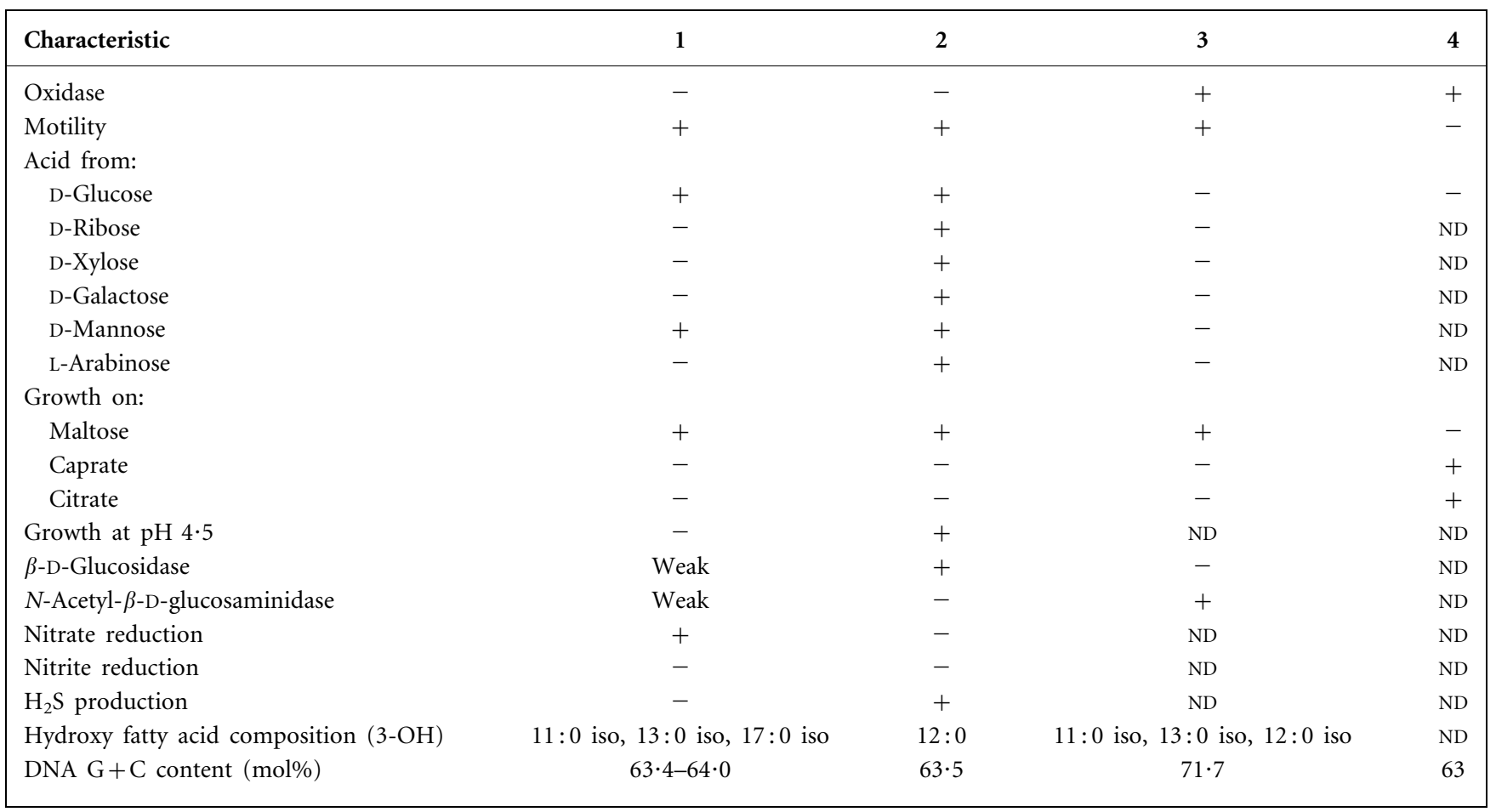


from Frateuria aurantia and Fulvimonas soli on the basis of some phenotypic features (Table 2). The novel bacterium could use $N$-acetyl $\beta$-D-glucosamine but Frateuria strains could not. Moreover, the novel bacterium did not have the general characteristics of Frateuria (i.e. growth at $\mathrm{pH} 3 \cdot 6$, production of $\mathrm{H}_{2} \mathrm{~S}$, ketogenesis from D-mannitol, acid production from almost all carbon sources; Swings et al., 1984). Frateuria strains have been isolated from Lilium auratum and from the fruit of Rubus parvifolius. The novel bacterium could be distinguished easily from members of the genera Fulvimonas and Rhodanobacter by DNA G $+\mathrm{C}$ content and by motility, respectively.

On the basis of their phenotypic, chemotaxonomic and phylogenetic characteristics, the novel isolates cannot be assigned to any recognized bacterial genus. Therefore, we propose Dyella japonica gen. nov., sp. nov. for these three strains.

\section{Description of Dyella gen. nov.}

Dyella (Dy.el'la. L. dim. ending -ella; N.L. fem. n. Dyella of Dye, in honour of Dr Douglas W. Dye, of New Zealand, who contributed to the taxonomic study of the genus Xanthomonas).

Cells are Gram-negative, catalase-positive and oxidasenegative. Colonies on nutrient agar are yellow. They do not grow in $\mathrm{AE}$ broth and do not produce $\mathrm{H}_{2} \mathrm{~S}$. The $\mathrm{G}+\mathrm{C}$ content of the DNA is approximately $62-64 \mathrm{~mol} \%$. The cellular fatty acid composition consists mainly of branched fatty acids, with $17: 1$ iso $\omega 9 c, 15: 0$ iso and $17: 0$ iso as the major fatty acids and 11:0 iso $3-\mathrm{OH}, 13: 0$ iso $3-\mathrm{OH}$ and $17: 0$ iso $3-\mathrm{OH}$ as the major hydroxy fatty acids. Q-8 is the major component of the quinone system. The type species of the genus is Dyella japonica.

\section{Description of Dyella japonica sp. nov.}

Dyella japonica (ja.po'ni.ca. N.L. fem. adj. japonica pertaining to Japan, from where the type strain and other strains originated).

Cells are straight rods $(0 \cdot 4 \times 1 \cdot 2 \mu \mathrm{m})$, motile by means of a single polar flagellum. Colonies grow well on nutrient agar. The conditions for growth are $10-37^{\circ} \mathrm{C}$ and $\mathrm{pH} 5 \cdot 6-8$; growth does not occur at $\mathrm{pH} 4 \cdot 6$. The optimum $\mathrm{pH}$ for growth is $6 \cdot 5-7 \cdot 2$. The optimum temperature for growth is $25-30{ }^{\circ} \mathrm{C}$; growth at 4 and $40{ }^{\circ} \mathrm{C}$ is very poor. Cells are nitrate reduction-positive; acids are produced from glucose, fructose and mannose, but not from mannitol. The other characteristics of the species can be found in Table 2. The $\mathrm{G}+\mathrm{C}$ content of the DNA of the type strain is $63.5 \mathrm{~mol} \%$.

The type strain, $\mathrm{XD}^{\mathrm{T}} 3^{\mathrm{T}}\left(=\mathrm{IAM} 15069^{\mathrm{T}}=\mathrm{DSM} 16301^{\mathrm{T}}=\right.$ ATCC BAA-939 ${ }^{\mathrm{T}}$ ), and strains XD10 (=IAM 15067) and XD22 (=IAM 15068) were isolated from soil in Tokyo, Japan.

\section{References}

Entani, E., Ohmori, S., Masai, H. \& Suzuki, K. (1985). Acetobacter polyoxogenes sp. nov., a new species of an acetic acid bacterium useful for producing vinegar with high acidity. J Gen Appl Microbiol 31, 475-490.

Ezaki, T., Hashimoto, Y. \& Yabuuchi, E. (1989). Fluorometric deoxyribonucleic acid-deoxyribonucleic acid hybridization in microdilution wells as an alternative to membrane filter hybridization in which radioisotopes are used to determine genetic relatedness among bacterial strains. Int J Syst Bacteriol 39, 224-229.

Felsenstein, J. (1985). Confidence limits on phylogenies: an approach using the bootstrap. Evolution 39, 783-791.

Felsenstein, J. (1989). PHYLIP - phylogeny inference package (version 3.2). Cladistics 5, 164-166.

Gillis, M., Vandamme, P., De Vos, P., Swings, J. \& Kersters, K. (2001). Polyphasic taxonomy. In Bergey's Manual of Systematic Bacteriology, 2nd edn, vol. 1, pp. 43-48. Edited by D. R. Boone, R. W. Castenholz \& G. M. Garrity. New York: Springer.

Kimura, M. (1980). A simple method for estimating evolutionary rates of base substitutions through comparative studies of nucleotide sequences. J Mol Evol 16, 111-120.

Lisdiyanti, P., Yamada, Y., Uchimura, T. \& Komagata, K. (2003). Identification of Frateuria aurantia strains isolated from Indonesian sources. Microbiol Cult Coll 19, 81-90.

Marmur, J. (1961). A procedure for the isolation of deoxyribonucleic acid from micro-organisms. J Mol Biol 3, 208-218.

Mergaert, J., Cnockaert, M. C. \& Swings, J. (2002). Fulvimonas soli gen. nov., sp. nov., a $\gamma$-proteobacterium isolated from soil after enrichment on acetylated starch plastic. Int J Syst Evol Microbiol 52, 1285-1289.

Mesbah, M., Premachandran, U. \& Whitman, W. B. (1989). Precise measurement of the $\mathrm{G}+\mathrm{C}$ content of deoxyribonucleic acid by high-performance liquid chromatography. Int J Syst Bacteriol 39, 159-167.

Nalin, R., Simonet, P., Vogel, T. M. \& Normand, P. (1999). Rhodanobacter lindaniclasticus gen. nov., sp. nov., a lindanedegrading bacterium. Int J Syst Bacteriol 49, 19-23.

Oyaizu-Masuchi, Y. \& Komagata, K. (1988). Isolation of free-living nitrogen-fixing bacteria from the rhizosphere of rice. J Gen Appl Microbiol 34, 127-164.

Poly, F., Monrozier, L. J. \& Bally, R. (2001). Improvement in the RFLP procedure for studying the diversity of nifH genes in communities of nitrogen fixers in soil. Res Microbiol 152, 95-103.

Saitou, N. \& Nei, M. (1987). The neighbor-joining method: a new method for reconstructing phylogenetic trees. Mol Biol Evol 4, 406-425.

Swings, J., De Ley, J. \& Gillis, M. (1984). Genus III. Frateuria Swings, Gillis, Kersters, De Vos, Gosselé and De Ley, 1980, 547 VP. In Bergey's Manual of Systematic Bacteriology, vol. 1, pp. 210-211. Edited by N. R. Krieg \& J. G. Holt. Baltimore: Williams \& Wilkins.

Swofford, D. L. (1998). PAUP* version 4. Phylogenetic Analysis Using Parsimony (*and Other Methods). Sunderland, MA: Sinauer.

Thompson, J. D., Higgins, D. G. \& Gibson, T. J. (1994). CLUSTAL W: improving the sensitivity of progressive multiple sequence alignment through sequence weighting, position-specific gap penalties and weight matrix choice. Nucleic Acids Res 22, 4673-4680.

Xie, C. H. \& Yokota, A. (2003). Phylogenetic analyses of Lampropedia hyalina based on the 16S rRNA gene sequence. J Gen Appl Microbiol 49, 345-349. 